\title{
Viktor frankl: a psychiatrist's view on how to find meaning in suffering
}

Volume 2 Issue 5 - 2015

\section{Opinion}

Is suffering incompatible with a good life, a happy life, one that is filled with meaning and purpose? No! But there are cultural and philosophical obstacles that may prevent many men and women from understanding and answering the question in the negative.

\section{America's fear of aging and suffering}

Today, especially in the United States, there is a fear of aging and suffering, because American culture worships being and staying young. ${ }^{1}$ Edith Weisskopf-Joelson, former professor of psychology at Purdue University, observes that in American culture, "the incurable sufferer is given very little opportunity to be proud of his suffering and to consider it ennobling rather than degrading."' It is also demoralizing to tell a person that his or her suffering is meaningless, discouraging him or her from being challenged by it. ${ }^{3}$

\section{Despair: suffering without meaning}

Since suffering is an inevitable part of life, one must try to find meaning in it. Terminally or chronically ill persons despair of their suffering, when they do not see any meaning to it. They see it as a waste of life, a useless experience. Hence, they conclude that suffering is meaningless. Psychiatrist Viktor Frankl writes, "despair is suffering without meaning". ${ }^{4}$ Those who despair of their suffering find life unbearable; as a result, they may want to die or commit suicide.

\section{Attitudinal Values: Choosing to find a meaning in suffering}

According to Frankl, "Life can be made meaningful ... through the stand we take toward a fate we no longer can change (an incurable disease, an inoperable cancer, or the like)". ${ }^{5}$ Since human beings have free-will, they must choose to see a meaning to their suffering. What makes the difference between despair and meaning? Frankl answers: The "attitude we choose toward suffering." Speaking as both a medical doctor and a psychiatrist, Frankl says, "Meaning rests on the attitude the patient chooses toward suffering"?

Psychologically and morally, it is better to choose to find a meaning in suffering than to suffer in despair. Frankl calls such a choice "attitudinal values" ${ }^{8}$. He explains its meaning, saying,

"Caught in a hopeless situation as its helpless victim, facing a fate that cannot be changed, man still may turn his predicament into an achievement and accomplishment at the human level. He thus may bear witness to the human potential at its best, which is to turn tragedy into triumph.". 9

\section{Becoming bitter or better from suffering}

Frankl, a Holocaust survivor, recalls the negative and positive responses of prisoners to suffering in the Nazi concentration camps. He says that a person "may remain brave, dignified and unselfish. Or

\author{
Timothy K Lent* \\ Immaculata and Villanova Universities, USA
}

\begin{abstract}
Correspondence: Timothy K Lent, Immaculata and Villanova Universities, 465 Irish Road Berwyn, PA. 193I2, USA, Tel: 6I0-
\end{abstract} 722-0758,Email tlent@comcast.net

Received: March 30, 2015 | Published: April 2I, 2015

in the bitter fight for self-preservation he may forget his human dignity and become no more than an animal". ${ }^{10}$ When a person's situation or circumstance changes for the worse, then his or her attitude must change for the better in order to accept it. ${ }^{11}$ The kind of person, then, that one becomes in suffering is the result of "an inner decision," not the result of suffering alone. ${ }^{12}$ To paraphrase Frankl in the first person singular: What kind of attitude will I have toward my suffering? Will I become bitter or better by it?

\section{Ennobled, not degraded, by suffering}

In one sense, suffering is certainly not good. Rather, it is a sign of the abnormality of the world. However, in another sense, suffering can be turned into a good deed, a moral value; by the way a person bears up under it. Suffering can "make" or "break" a person, either ennobling or degrading him or her. As Plutarch, the ancient Greek historian, says, "The measure of a man is the way he bears up under misfortune". ${ }^{13}$ That, perhaps, is why the Russian novelist Fyodor Dostoevski writes, "There is only one thing that I dread: not to be worthy of my sufferings". ${ }^{14}$ For Frankl, "the right kind of suffering is in itself a deed, nay, the highest achievement which has been granted to man". ${ }^{15}$

\section{Making sense of suffering}

Does suffering have meaning? Yes! Jewish artist and Holocaust survivor Yehuda Bacon says, "Suffering ... can have a meaning if it changes you for the better". ${ }^{16}$ Similarly, Frankl writes, "Every life, in every situation and to the last breath, has a meaning, retains a meaning. This is equally true of the life of a sick person, even the mentally sick. The so-called life not worth living does not exist". ${ }^{17}$

Suffering in itself need not be a waste of life. However, there is a lot of wasted suffering in the world, because many will not choose to find a meaning to it, thus making their suffering senseless instead of making sense of suffering. 


\section{Acknowledgments}

None.

\section{Conflicts of interest}

Author declares there are no conflicts of interest.

\section{Funding}

None.

\section{References}

1. Viktor E Frankl. Psychotherapy and Existentialism: Selected Papers on Logotherapy Simon and Schuster Inc., New York, USA. 1967. p. 31-84.

2. Edith Weisskopf-Joelson. Logotherapy and Existential Analysis. Psychother Psychosom. 1958;6(3):193-204.

3. Joyce Travelbee. Interpersonal Aspects of Nursing. In: Viktor E Frankl (1969) The Will to Meaning: Foundations and Applications of Logotherapy New American Library, New York, USA. 1966. p.124.

4. Viktor E Frankl. The Unconscious God, Washington Square Press, New York, USA. 1985. p.137.

5. Viktor E Frankl. Psychotherapy and Existentialism, Simon and Schuster, New York, USA. 1967.
6. Ibid, p. 24.

7. Viktor E Frankl. The Will to Meaning: Foundations and Applications of Logotherapy, New American Library, New York, USA. 1969. p.131.

8. Viktor E Frankl. The Doctor and the Soul: From Psychotherapy to Logotherapy, (3rd edn), Richard and Clara Winston, Vintage Books/ Random House, New York, USA. 1973. p.44

9. Viktor E Frankl, The Unconscious God, op. cit. p.125-126.

10. Viktor E Frankl. Man's Search for Meaning, Pocket Books, New York, USA. 1963. p.107.

11. Viktor E Frankl, The Doctor and the Soul, op. cit. p.80.

12. Viktor E Frankl. Man's Search For Meaning. 1963. p.105.

13. Plutarch, quoted in Viktor E Frankl, The Unconscious God. p.126.

14. Fyodor Dostoevski, quoted in Viktor E Frankl, Man's Search For Meaning. p.105.

15. Viktor E Frankl, Psychotherapy and Existentialism. p.128.

16. Yehuda Bacon, quoted in Viktor E Frankl, The Will to Meaning, op. cit. p.79.

17. Viktor E Frankl, Psychotherapy and Existentialism. p. 129 